\title{
VARIA:
}

\section{Reklamní tiskoviny pro školáky v letech 1918-1938. Pohled do archivních fondů Muzea Komenského v Přerově}

\author{
Helena KovÁŘOvÁa \\ a Muzeum Komenského v Přerově
}

\section{Úvod}

S rozvojem průmyslu a metod komerční propagace v období první Československé republiky začala reklama cílit také na děti - vhodnou plochu nabízely drobné papírové předměty určené školákům. Svůj prostor zde našli výrobci školních potřeb, obuvi, potravin, drogistického zboží a také spořitelny. O vývoji reklamních tiskovin vypovídají, mimo jiné, archivní prameny Muzea Komenského v Přerově a na základě jejich analýzy je možné nejen zjistit více informací o problémech tehdejšího života obklopovaného reklamou, ale i z širšího hlediska přemýšlet o životě meziválečné školy a o každodenním vnímání jejími aktéry, tedy žáky, rodiči a učiteli.

Hlavní badatelskou obtíží je fakt, že se v době vzniku reklamních dokumentů nevěnovala žádná pamětová instituce jejich systematickému sběru a uchovávání, do fondů se dostávaly jen nahodile. V současné době je trh s těmito předměty stále bohatý, a to díky popularitě materiálu u soukromých sběratelů. Otázkou zůstává, jak velká část z dobové produkce v nabídce chybí. Muzeum Komenského v Přerově se již delší dobu zaměřuje na cílené shromažd'ování tohoto materiálu, v textu je také využito informací získaných monitorováním nabídky předmětů v rámci on-line aukcí a nabídek.

Často je velmi nesnadná datace materiálu - u některých dokumentů se daří odvodit rok vzniku, jinde pouze širši časové rozpětí. Proto lze jen těžko určit, zda produkci ovlivnilo vydání tzv. prŕídavkového zákona v roce $1935 .^{1}$

\section{Nové formy reklamy}

Na přelomu 19. a 20. století směřovala reklama související se školou především k dospělým bud' $\mathrm{k}$ učitelům (inzerce $\mathrm{v}$ odborných časopisech, katalogy, letáky apod.), nebo k rodičům (inzerce $\mathrm{v}$ tisku na školní brašny, oděv do školy atd.). Po přerušení rozvoje komerční propagace $\mathrm{v}$ době první světové války a následném intermezzu poválečné obnovy navázal vývoj nejprve na tradiční formy. Osvědčenými způsoby zůstávaly plakát, inzerce a rozesílání letáků. Výrobci ale hledali nové vhodné plochy, kterými by oslovili další cílovou skupinu školní mládež. Nabízely se piják (savý papír), rozvrh hodin, desky nebo papírový obal

\footnotetext{
${ }^{1}$ Zákon č. 75/1935 Sb. zakazoval přidávat ke zboží dárky vysoké hodnoty, povoleny zůstaly pouze cenově bezvýznamné maličkosti, mezi nimi např. dětské pohádky, kalendáre, rozvrhy hodin atd.
} 
na sešity, které bylo možné potisknout obrázkem s textem ve stylu podobném plakátu. Jako nejvýraznější př́klad tohoto transferu je postava školáka od firmy Leonhardi.

Formu nabídkového letáku přeneseného na rozvrh hodin i se stručným popisem zboží (včetně velikostí bot a ceny) používala firma Bat'a. Ta do českého prostředí přnášela teoretické základy racionalizované organizace výroby a prodeje, včetně oblasti komerční propagace (Hlouchová, 2015, s. 54-69). Její reklamní oddělení plánovalo během celých třicátých let 20. století kampaně zaměřené mimo jiné na začátek školního roku (Bazgerová, 2011, s. 5864). Zvolený motiv, např́iklad usmívající se školačka před černou tabulí pro rok 1938, se systematicky opakoval na všech komunikačních prostředcích (plakát, inzerát, brožura, leták, materiál pro výkladní skříň atd.). Kromě rozvrhů hodin se připravovaly se také další speciální reklamní dárky, např. tužky, gumy a pravítka.

Ve sledovaném období se objevovaly inovativní nápady na série tiskovin určené školákům v oblasti populárních reklamních pohádek, např. příběhy odehrávající se ve škole. Pro děti bylo určeno množství sběratelských sad kartiček, v nichž lze najít přírodovědná, zeměpisná, vlastivědná i historická témata. Snahu zaujmout přidanou edukativní hodnotou nejdále rozvinula firma Schicht, jejíž produkce je podrobněji popsána v další části textu. Pro potřeby školáků byly určeny také drobné zápisníky či kalendáře doplněné obrázky, poučnými i zábavnými texty. Některé z těchto druhů tiskovin (např. rozvrhy hodin, papírová měřítka) jsou stálicí v reklamních tiskovinách dodnes. Jiné zanikly, např. pijáky, kvůli technologickému pokroku v oblasti psacích potřeb.

\section{Reklamní strategie}

S postupujícím vývojem reklamy se obchodníci a výrobci stále více zaměřovali na děti, které disponovaly financemi sice jen v omezeném množství, ale mohly ovlivňovat rodiče. V tomto směru je vývoj podobný jako $\mathrm{v}$ hračkářském průmyslu. Objevovaly se pobídky ke sdílení reklamních materiálů s rodiči (např. firma Pilnáček), dále doporučení na zakoupení vhodných dárků pro rodiče nebo návody pro jejich vytvoření (potravinářské prŕsady KVETA). U drogistických výrobků, zejména pracích prostředků a mýdel, reklamy zobrazovaly usměvavé matky při jedné z nejtěžších prací v domácnosti - při praní prádla (Pilnáček, Schicht). Mnohdy doprovodný text hlásal, že použivání určitého výrobku ulehčilo ženě práci a zajistilo jí více času pro děti, a objevila se dokonce i rada, aby děti „poučily mamičku“ o vhodnosti používání daného výrobku (Otta).

Výrobci počítali také $\mathrm{s}$ tím, že je dětem svěřován drobný nákup pro domácnost. V těchto př́padech se objevovaly agresivnější formy reklamy, např. „Děti, při nákupu v konsumu vždycky řkněte - Ale já chci jenom dobré věci, ty co jsou se značkou VDP“. Snahu vychovávat zákazníka $\mathrm{k}$ věrnosti značce vyjadřuje např. verš „Do školy s učením, od kupce s hradeckou".

Jednou ze strategií, jak se přiblížit $\mathrm{k}$ dětem, bylo představení výrobku jako nutné součásti běžného dne školáka. Využívaly ji zejména firmy vyrábějící kávoviny (Kolínská cikorka, žitná káva Oveka, Franckovka a Perola), které vycházely z reality českých domácností a oblíbenosti daných výrobků. Poněkud rozporuplně vyznívala obdobná taktika u výrobců 
čokolády a cukrovinek (RUPA, Meinl apod.), které nebyly běžnou a cenově dostupnou součástí snídaní a svačin velké části školáků sledovaného období. Přesto je patrné, že děti jsou zde považovány za členy domácnosti, kteří mohou ovlivňovat rodinné výdaje.

Další styčnou plochou reklamy a školy se stala oblast hygieny a zdraví, kde výrobci s oblibou využívali obecně známá úsloví, např. „Čistota pưl zdravi“" (firma Schicht i Pilnáček) nebo „V domě, kde čistota sídlí, zdraví a veselost bydlí!“ pod obrázkem školy (firma VIM, srov. Klomfarová 2014, s. 37). Jindy byla reklama spojována se zdravotnickou osvětou, např́iklad průběh školní exkurze v lékárně.

Atraktivitu reklamy se výrobci snažili již tradičně zvýšit součinností se známými výtvarníky (srov. Vošahlíková, 1999, s. 117), kteří se většinou neomezovali na jednu firmu. Mezi nejvýraznější patřili Marie Fischerová-Kvěchová (např. Otta Rakovník, Velimská cikorka, Kosmos Čáslav, Schnöbling - zubní pasta Thymolin), Artuš Scheiner (Otta Rakovník), Věnceslav Černý (BRAVO, Národní podnik, banka Slavie atd.).

Aktivní v produkci reklamních předmětů pro děti byly spořitelny a kampeličky. Hlavní součástí rozvrhů hodin, kalendářů a pijáků býval poučný text nabádající ke spořivosti a zodpovědnému chování. Široké využití zde našly citáty slavných osobností nebo snaha ukázat výhody dlouhodobého spoření pro spokojený život v dospělosti, respektive ve stárí, tedy výhledy do št’astné budoucnosti.

Využíván byl i odkaz k aktuální politické situaci nebo k národní hrdosti. Např́klad v roce 1935 vznikl rozvrh hodin se sloganem „Tatíček Masaryk odstoupil! President Dr. Ed. Beně̌ nastoupil!“" a s vyobrazeními obou politiků (okresní záložna Český Dub). V době zintenzivnění příprav na obranu republiky po roce 1935 vydala Kolínská cikorka sérii kartiček s obrázky uniforem a odznaků československé armády. ${ }^{2}$ V roce 1937 se pražská firma Schnöbling spolupodílela na propagační kampani Ministerstva národní obrany podporující předvojenskou výchovu.

\section{Reklama produktů pro školu}

Mezi nejdůležitější výrobky určené pro školu patřil inkoust. Za formu reklamy lze považovat již samotnou etiketu lahvičky zdobenou propracovanými ornamenty. Již v 19. století se jednalo o poznávací znamení určité firmy (srov. Vošahlíková, 1999, s. 57). Realistické obrázky výrobků proto zůstávaly jedním z velmi frekventovaných námětů komerční propagace, nebot' umožňovaly rychleji rozeznávat firemní produkty od konkurenčního zboží. Ve sledovaném období je využívaly např́iklad firmy Leonhardi (Lněničková, 2007, s. 89), L. \& C. Hardtmuth Koh-i-noor, Grafo (Liška, 2005, s. 118-120), Národní podnik, Arfis nebo ABO. Obrázky doprovázel text o výjimečnosti dané značky, např́klad „Nežádej prostě ,nějakou tužku' nebo ,nějakou pryž' ... Žádej proto vždy ,Hardtmuthovu tužku' nebo ,Hardtmuthovu pryž!"“

Podnik Leonhardi používal již od konce 19. století další velmi úspěšný grafický prvek svých reklam přenesený z plakátu. Jednalo se o postavu smějícího se školáka v námořnickém oděvu,

\footnotetext{
${ }^{2}$ Kolínská cikorka využívala i úplně odlišné strategie, např́ílad sport. Na rubech rozvrhů bývaly fotbalové dresy mužstev hrajících státní ligu.
} 
se slaměným kloboukem a školní brašnou, který v pravé ruce zdvihal nad hlavu lahvičku inkoustu. Objevila se i modernizovaná verze tohoto úspěšného symbolu v soudobém oděvu. O napodobení se pokoušely další firmy, např. Národní podnik (kreslil Otto Ušák), Arfis, L \& C Hardtmuth, Grafo, ale jejich postavy školáků v reklamních rozvrzích hodin nenavozují $\mathrm{v}$ divákovi tak lákavý dojem z výrobku jako u firmy Leonhardi.

\section{Reklama na produkty mimo oblast školy}

Mezi podniky, jejichž sortiment přímo nesouvisel se vzděláváním, vynikaly v inovativní reklamě pro školáky tř̆i továrny drogistického zboží: Schicht z Ústí nad Labem, Otta z Rakovníku a Pilnáček z Hradce Králové. Firma Schicht měla podobně jako Bat'a vlastní reklamní oddělení. Velký důraz kladený na komerční propagaci pomohl továrně s velkým rozsahem sortimentu (mýdlo, prostředky na praní, kosmetika, pokrmové tuky) překonat problémy způsobené jak rozpadem monarchie, tak velkou hospodářskou krizí (Blíže Králová, 1995, s. 118-120; srov. Urychová, 2018, s. 23-58). V reklamách určených školákům vsadila na edukační přesah spojený s propagací značky Schicht - například srovnáním známých výškových staveb světa s továrním komínem v Ústí nad Labem.

Schichtova strategie postupovala $\mathrm{v}$ tomto směru ještě dále. Vycházely celé série drobných vzdělávacích pomůcek pro děti, např́iklad kartičky Drobné práce pro hochy a Drobné práce pro dívky s jednoduchými návody na výrobu hraček. Od začátku třicátých let vycházela série „Okénka do světa - Lehrtafeln“, která měla ambice vytvořit malou dětskou ilustrovanou encyklopedii, a to v české a německé jazykové mutaci (pobočný závod na výrobu tuků Vittelo a Ceres). Na jednotlivých listech se stř́daly náměty $\mathrm{z}$ oblasti př́rody, techniky, historie a kultury, průmyslu, geografie, sportu, ale i popis samotné výroby, který neztrácel vzdělávací hodnotu obsahu. Okénkový obrázkový cyklus na přední straně byl vždy čísly propojen s popisným textem na rubu, což mohlo odkazovat k Orbis pictus. Pečlivě zpracovaná témata je možné srovnávat s dobovými didaktickými pomůckami. Problémem byla nesystematičnost a nutnost postupného shromažd’ování sady.

Velkou pozornost reklamě věnovala také rakovnická firma na výrobu drogistického zboží Otta, která na počátku 20. století úspěšně zvládla konkurenci levného mýdla Schicht zavedením tzv. bílého mýdla (srov. Vítková, 2015, s. 30-31). Jeho poznávacím znamením se stal rak, zvíře ze znaku města Rakovník. Firma dokázala graficky velmi nápaditě využít jak symbolu raka, tak svého názvu, a to vytvořením dvojice postaviček Otáček a Ráček. Panáček Otáček vznikl otočením názvu OTTA a přikreslením obličeje do písmene O. Zápletky jejich odlehčených cestovatelských príhod v komiksovém stylu se opíraly o charakteristiky regionu (obecná klišé, napřr. obilné lány a buchty na Hané, bača a stádo ovcí na Slovensku, Eskymák a mrož v krajině u polárního kruhu) a na ně navazovalo i vyřešení problému pomocí výrobku firmy (mýdlo, prací prášek atd.). Kvalita jednotlivých př́iběhů ovšem kolísala.

Z tehdejší běžné produkce reklamních pohádek (Vítková, 2015, s. 40-42) vybočuje soubor realisticky líčených př́hod žáka první třídy obecné školy. Autorem textu je Josef Klaban 
(*1889), ${ }^{3}$ řídící učitel obecné školy v Bystřici u Libáně, autor několika knih pro děti (Bartoňová, 2003, s. 126-134). Původní strach hlavního hrdiny ze školního prostředí se v nich promění ve velmi pozitivní vztah ke škole i třídnímu kolektivu a obdiv k učiteli, nebot' jej zachránil před utonutím.

Z řady reklamních tiskovin je třeba upozornit na speciální sérii s názvem Pilnáčkova abeceda ve formátu reklamní pohádky určené nejmladším školákům. Každému písmenu byl věnován jeden dvoulist s krátkou básničkou a tematickým obrázkem.

V dalších edicích Pilnáčkových pohádek vycházely př́iběhy, v nichž hlavní roli hrály výrobky firmy, at' už se jednalo o přepracované klasické syžety, nebo soudobé náměty. Podobnou strategii používaly i další firmy.

Firma vytvořila také „Školní zápisník“, dětskou variantu proslulého „Pilnáčkova kalendáře pro naše hospodyňky“. Kromě reklamních sdělení obsahoval pobídky k dodržování pravidel osobní hygieny, cvičení v sokolském duchu a určité sebekázni. Objevilo se také papírové „Pilnáčkovo pravítko“s nápisem „Zákonem chráněno - napodobení se stíhá“, kde byla hrana doplněná o kovovou lištu, aby lépe drželo tvar.

\section{Závěr}

Specifický druh reklamy určený školní mládeži byl v průběhu let 1918-1938 výrobci čím dál oblíbenější. Vyvíjely se nové formy a strategie „školní reklamy“. Primárně byla určena dětem, dospělí (především rodiče) se s ní měli seznamovat na jejich popud. V první řadě tyto materiály produkovali výrobci školních potřeb, u nichž komerční propagace námětově nevybočila z okruhu školního prostředí. Daleko inovativnější pak museli být producenti zboží mimo školu. Jedním z nejzajímavějších postupů bylo vytváření drobných vzdělávacích pomůcek. Další metodou bylo propojení daného výrobku s námětem školy a s činnostmi dětí v rodině nebo mezi kamarády. Uplatnily se také obecně používané strategie, například výchova zákazníka k věrnosti značce. V momentě, kdy se reklama dotkla konkurentů, stávala se agresivnější, např́klad rady pro nákup. Reklama se snažila ovlivnit postoj školáků k propagovaným výrobkům a vsázela na možnosti dětí ovlivňovat také smýšlení a tržní chování rodičů.

\footnotetext{
${ }^{3}$ Psal také pod pseudonymy Josef Jarmin, J. K. Hradský a Jiří Pohora.
} 


\section{Primární zdroje}

Fond archiválie, písemnosti a dokumentace dějin školství a komeniologie. Muzeum Komenského v Přerově.

\section{Literatura}

BARTOŇOVÁ, Jaroslava, 2003. Divadlo v Bystřici. Listy Starohradské kroniky. Roč. 26, č. 3-4, s. 126-134. ISSN 1210-6194.

BAZGEROVÁ, Eva, 2011. Komunikace se zákazniky firmy Bata v meziválečném období. Brno. Magisterská diplomová práce. Filozofická fakulta Masarykovy univerzity, Ústav hudební vědy.

HLOUCHOVÁ, Kateřina, 2015. Proměny československé reklamy 1918-1989. Brno: Václav Klemm - Vydavatelství a nakladatelství. ISBN 978-80-87713-12-9.

KLOMFAROVÁ, Jana, 2014. Zobrazení moderní rodiny v reklamě v období první republiky. Brno. Magisterská diplomová práce. Filozofická fakulta Masarykovy univerzity, Ústav hudební vědy.

KRÁlOVÁ, Iva, 1995. Schichtovy závody. In: Dějiny města Ústí nad Labem. Ústí nad Labem: Město, s. 118-120. ISBN 80-239-3245-4.

LIŠKA, Pavel, 2005. Kapitoly z historie výroby školních a kancelářských potřeb českobudějovických podniků. [České Budějovice]: Pavel Liška.

LNĚNIČKOVÁ, Jitka, 2007. České \& moravské obalové sklo: historie a současnost = Bohemian \& Moravian container glass: history and the present. Plzeň: G2 studio. ISBN 97880-903893-1-1.

URYCHOVÁ, Charlene, 2018. Marketingová komunikace Schichtových tukových závodi̊ na přelomu 19. a 20. století. Praha. Bakalářská práce. Fakulta sociálních věd Univerzity Karlovy, Institut komunikačních studií a žurnalistiky.

VÍTKOVÁ, Michaela, 2015. František Otta (1848-1939), osobnost Rakovnika na prelomu 19. a 20. století. Praha. Bakalářská práce. Pedagogická fakulta Univerzity Karlovy, Katedra dějin a didaktiky dějepisu.

VOŠAHLÍKOVÁ, Pavla, 1999. Zlaté časy české reklamy. Praha: Karolinum. ISBN 80-7184715-1. 


\section{Obrazová př́loha}

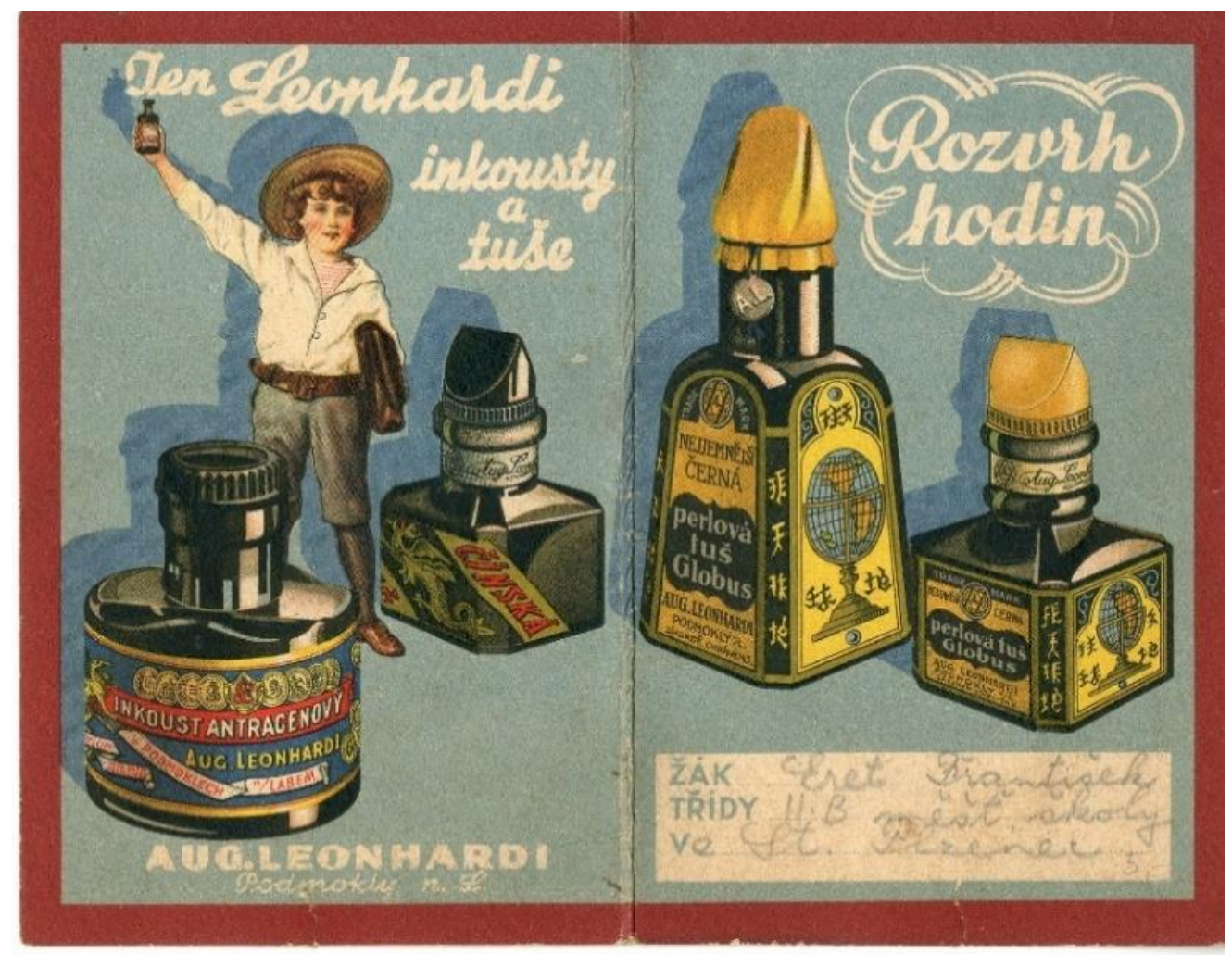

Obr. 1 - Rozvrh hodin s postavou „školáka Leonhardi“. Podmokly nad Labem (Bodenbach bei Tetchin). Zdroj: Muzeum Komenského v Přerově.

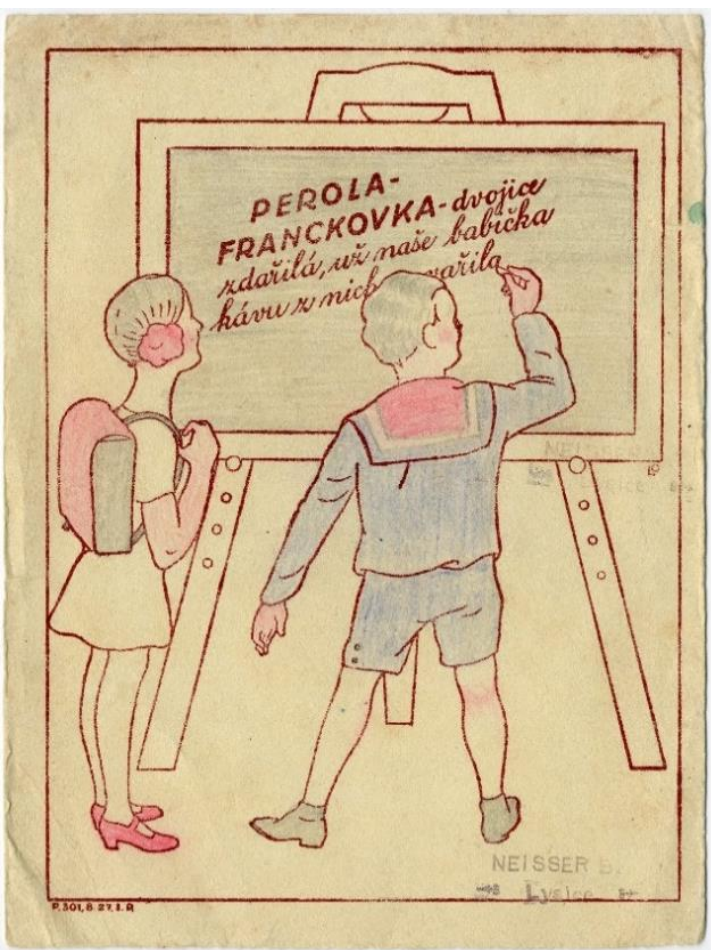

Obr. 2 - Piják vydaný firmou Josefa Francka, Pardubice. Zdroj: Muzeum Komenského v Přerově. 

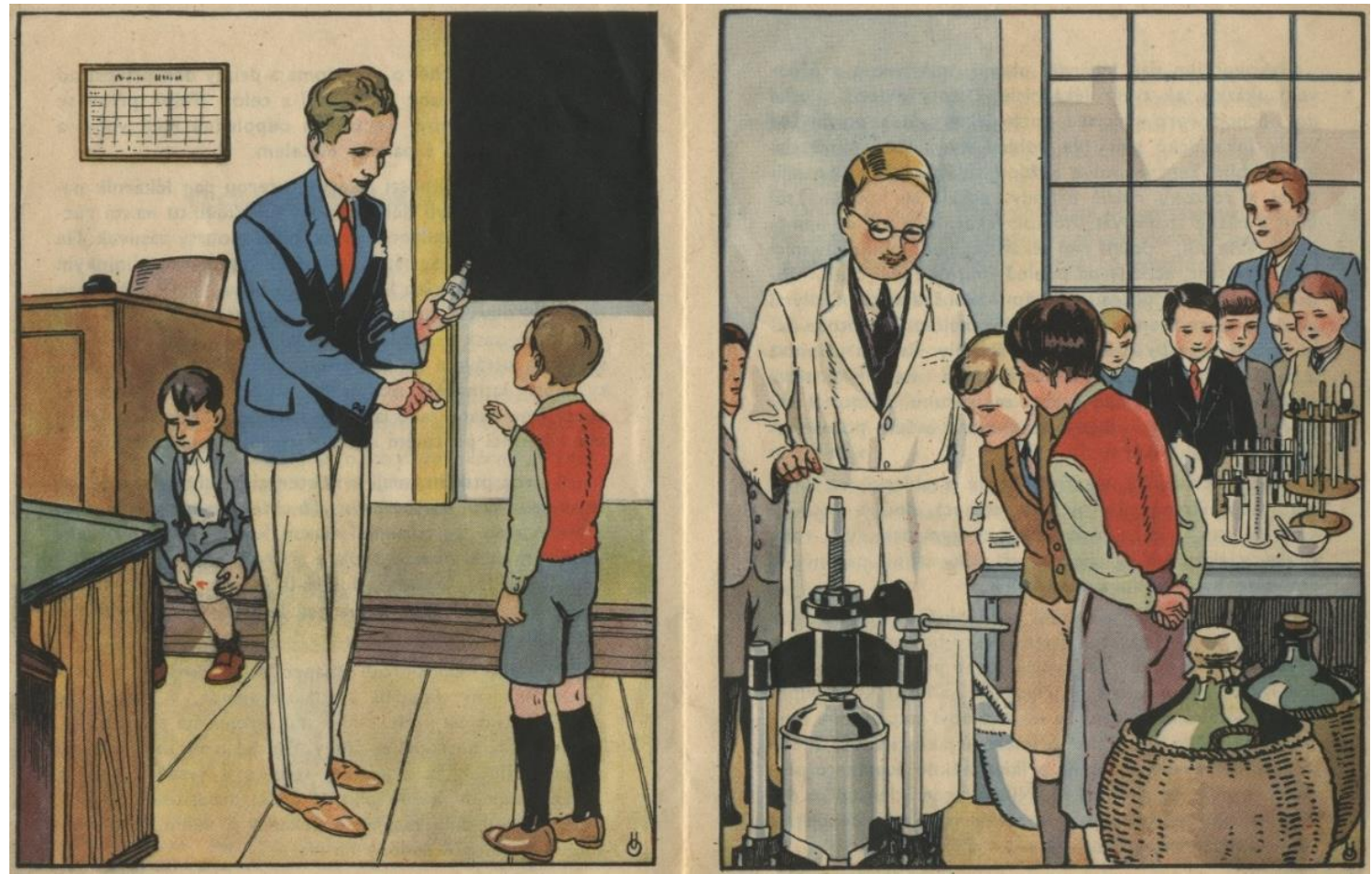

Obr. 3 - Reklamní př́iběh Vycházka do lékárny. Text Břetislav J. Větrovský, ilustrace Otto Ušák. Vydal časopis Praktický lékárník. Zdroj: Muzeum Komenského v Přerově.

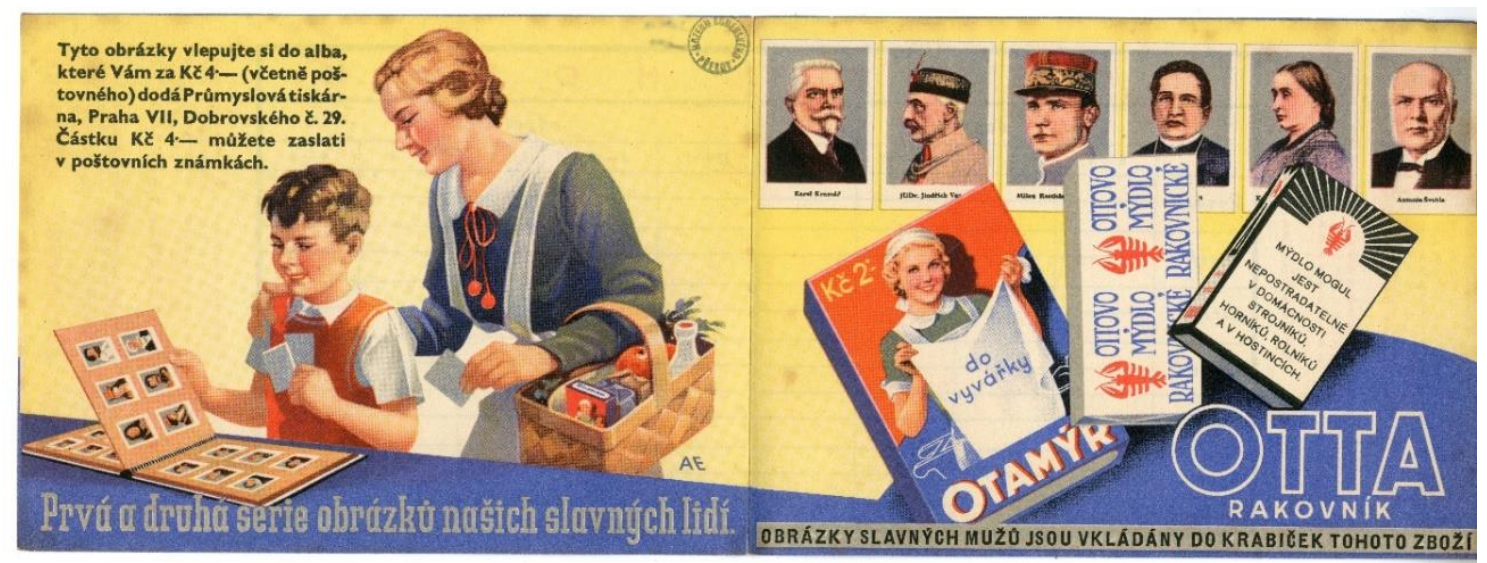

Obr. 4 - Rozvrh hodin propagující sběratelskou sérii kartiček. Vydala firma Otta Rakovník. Zdroj: Muzeum Komenského v Přerově. 


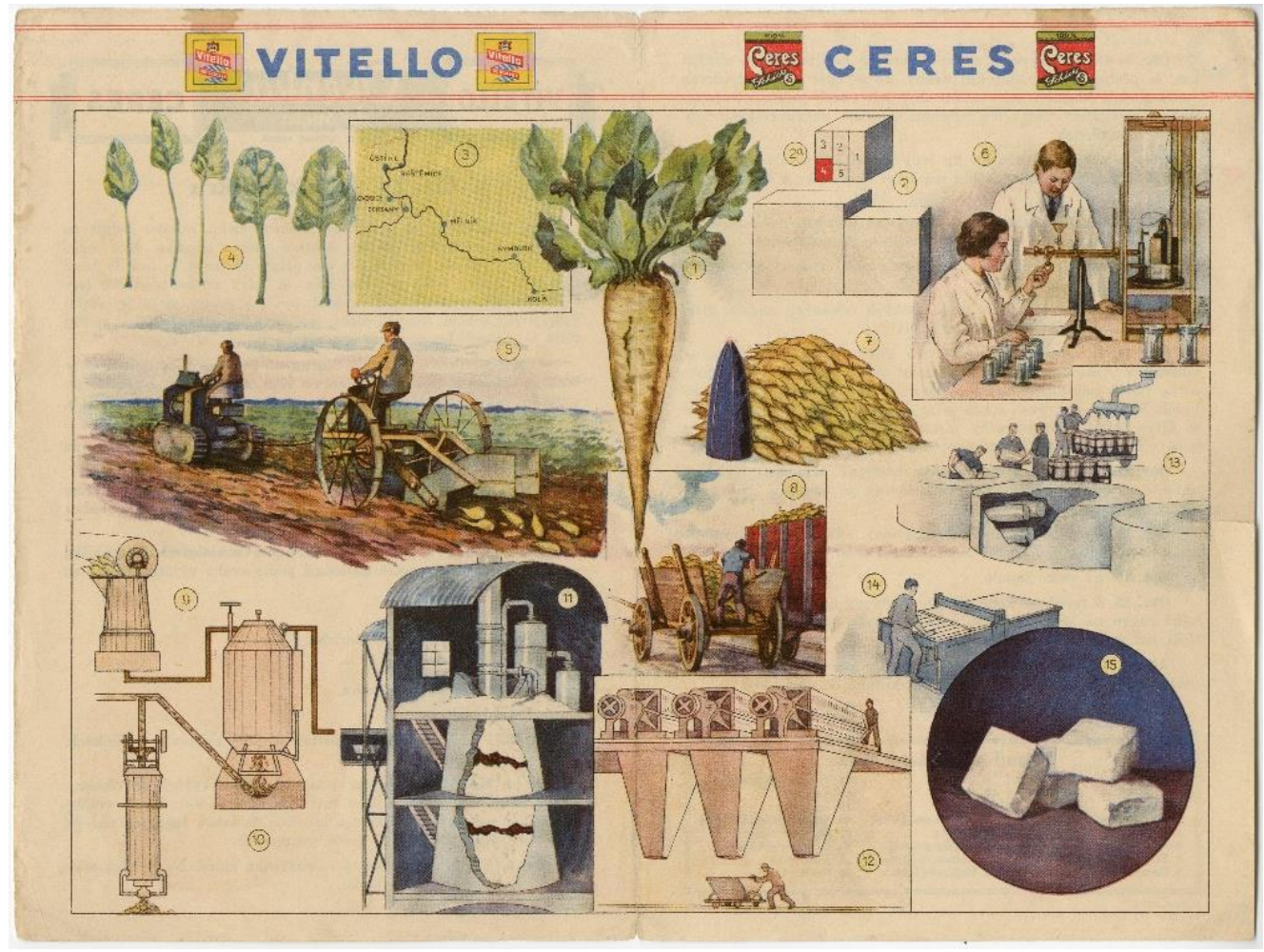

Obr. 5 - Kostka cukru. 24. díl série Okénka do světa / Lehrtafeln. Vydávala firma Schicht, Ústí nad Labem, pobočný závod Křešice. Zdroj: Muzeum Komenského v Přerově.

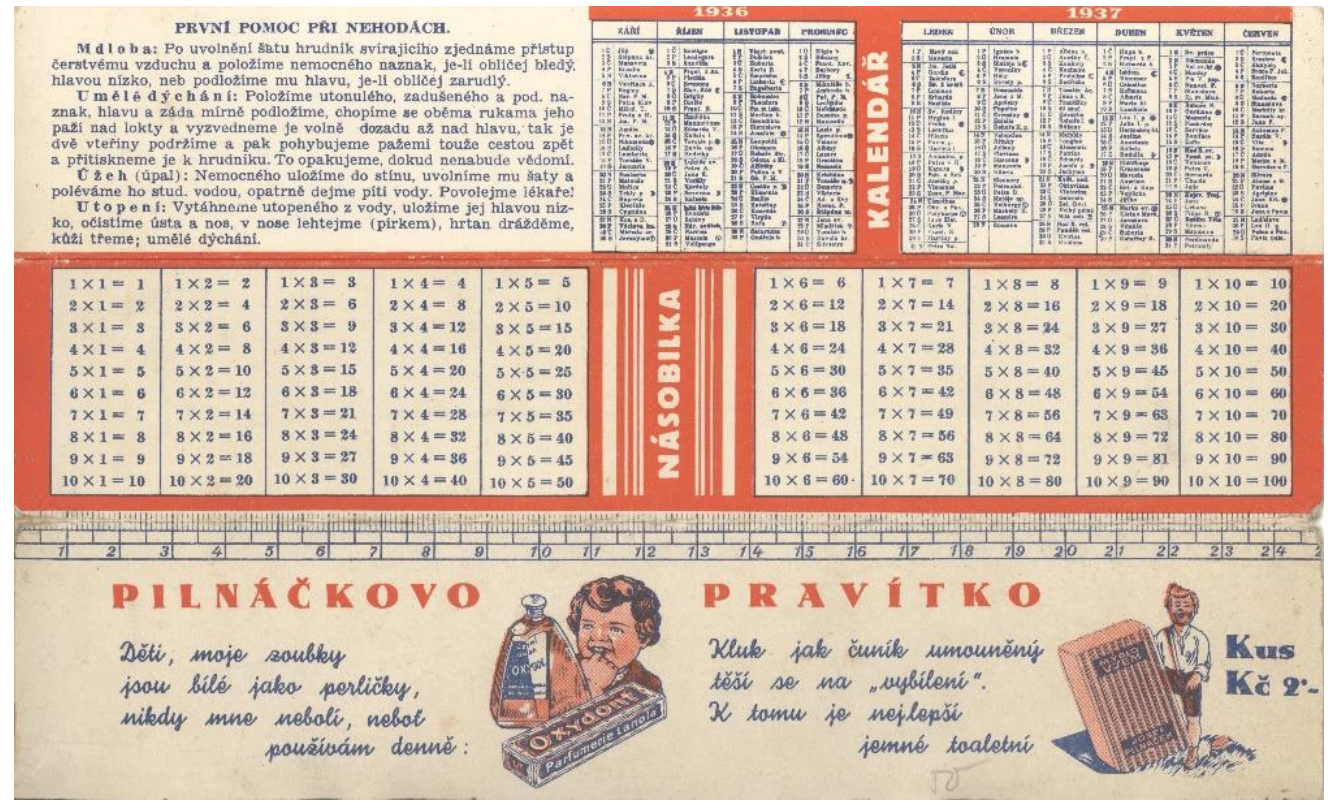

Obr. 6 - Patentované pravítko s rozvrhem hodin, kalendářem a násobilkou. Vydala firma Pilnáček, Hradec Králové (1936). Zdroj: Muzeum Komenského v Přerově. 